\title{
Essence and Phenomenon in Linguistic Content and Expression
}

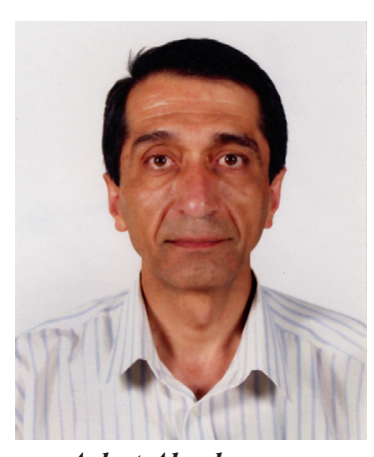

Ashot Abrahamyan

The interrelation between content and expression in

1 language is not identical with that in extralinguistic reality. In the extralinguistic world it is an interrelation between essence and phenomenon. The world itself is split up into essence and phenomenon; the division of language into content and expression genetically is connected with this division and is the former's reflection and echo. At the same time, as part of the world, language has its essence and phenomenon. Hence, in language neither expression is identical to phenomenon, nor content - to essence. In language, essence - phenomenon and content - expression pairs form a net of interpenetration, the knots of which are the essence of content and the phenomenon of content, the phenomenon of expression and the essence of expression, the content of essence and the expression of essence, the expression of phenomenon and the content of phenomenon. Naturally, there occur crossings and coincidences among them.

Thus, the content of essence is identical with the essence of content, the content of phenomenon is identical with the phenomenon of content, the expression of phenomenon is identical with the phenomenon of expression, the expression of essence is identical with the essence of expression. The picture gets more complicated when the gradual manifestations of essence, phenomenon, content and expression are being considered in language in general, in a certain language and in individual's language ${ }^{1}$. A certain language, as a link in the chain of manifestations of the language essence through phenomenon, is the phenomenon of language in general and the essence of individual's language. Therefore there exists coincidence between the phenomenon of content (the content of phenomenon) of language in general and the essence of content (the content of essence) of an individual's language, the phenomenon of expression (the expression of phenomenon) of language in general and the essence of expression (the expression of essence) of an individual's language.

The four results of the synthesis of content and expression, essence and phenomenon in their threefold manifestations present the table given below. 


\section{LANGUAGE IN GENERAL, A CERTAIN LANGUAGE INDIVIDUAL'S LANGUAGE}

\begin{tabular}{|c|c|c|c|}
\hline & $\begin{array}{l}\text { LANGUAGE IN } \\
\text { GENERAL }\end{array}$ & $\begin{array}{l}\text { A CERTAIN } \\
\text { LANGUAGE }\end{array}$ & $\begin{array}{c}\text { INDIVIDUAL'S } \\
\text { LANGUAGE }\end{array}$ \\
\hline $\begin{array}{c}\text { ESSENCE OF CONTENT } \\
\text { (CONTENT OF } \\
\text { ESSENCE) }\end{array}$ & Extralinguistic reality & $\begin{array}{c}\text { Reflection of } \\
\text { extralinguistic reality in } \\
\text { human reason }\end{array}$ & $\begin{array}{c}\text { Semantic system of a certain } \\
\text { language }\end{array}$ \\
\hline $\begin{array}{c}\text { PHENOMENON OF } \\
\text { CONTENT (CONTENT } \\
\text { OF PHENOMENON) }\end{array}$ & $\begin{array}{c}\text { Semantic systems of } \\
\text { languages }\end{array}$ & $\begin{array}{l}\text { Semantic systems of } \\
\text { individual's languages }\end{array}$ & $\begin{array}{c}\text { Situative reference of } \\
\text { speech }\end{array}$ \\
\hline $\begin{array}{c}\text { ESSENCE OF } \\
\text { EXPRESSION } \\
\text { (EXPRESSION OF } \\
\text { ESSENCE) }\end{array}$ & $\begin{array}{c}\text { Existence of voice as } \\
\text { property of matter }\end{array}$ & $\begin{array}{c}\text { Articulated sounds as } \\
\text { possibility of expression } \\
\text { of content }\end{array}$ & $\begin{array}{c}\text { Phonetic system of a certain } \\
\text { language }\end{array}$ \\
\hline $\begin{array}{l}\text { PHENOMENON OF } \\
\text { EXPRESSION } \\
\text { (EXPRESSION OF } \\
\text { PHENOMENON) }\end{array}$ & $\begin{array}{c}\text { Phonetic systems of } \\
\text { languages }\end{array}$ & $\begin{array}{l}\text { Phonetic systems of } \\
\text { individual's languages }\end{array}$ & Speech phonation \\
\hline
\end{tabular}

As it can be seen from the table, the phenomenon of language in general and the essence of individual's language fall into the same category but not always coincide in their comprehension. The phenomena of the content of language in general are the semantic systems of all languages, whereas the essence of the content of an individual's language is the semantic system of one language which acts as realization of one of the possibilities. Similarly, the phenomena of the expression of language in general are the phonetic systems of all languages, only one of which is the essence of expression of the individual's language. That is, there exists a relationship of possibility and reality between the phenomenon (of the content and expression) of language in general and the essence (of the content and expression) of an individual's language ${ }^{2}$.

The phenomenon of the content of language in general is a set of possibilities, the realization of one of which becomes the essence of the content of an individual's language. Similarly, the phenomenon of the expression of language in general is realized through the essence of the expression of an individual's language. Thus, the essence of an individual's language is one of the possible realizations of the phenomena of language in general.

The summary table of essence and phenomena of content and expression reveals another interesting fact: language in general and individual's language get nearer not only in the phenomenon of the first and the essence of the second, but also in the essence of the first and the phenomenon of the second.

It may seem that the essence of language in general and the phenomenon of individual's language, being polar edges of essence and phenomenon, must have been 
extremely drawn apart from each other. However, the situation is quite different. Starting from the extralinguistic reality in the essence of content of language in general linguistic reality returns to the same extralinguistic reality in the phenomenon of the content of individual's language, concentrating in that particular case on one of many possible situations. The essence of the expression of language in general, which is voice, is a feature of matter, i.e. is of extralinguistic, objective nature. It has speech articulation as its type: it is voice, too, but it is a vocal signal specified by language and thus is the linguistic realization of various manifestation possibilities of the sound feature.

It can be concluded that there also exists a relationship of possibility and reality between the essence of language in general and the phenomenon of individual's language: the essence of language in general is a multitude of possibilities, one of which is realized as phenomenon of an individual's language.

The following figure illustrates the double transition between language in general and individual's language.

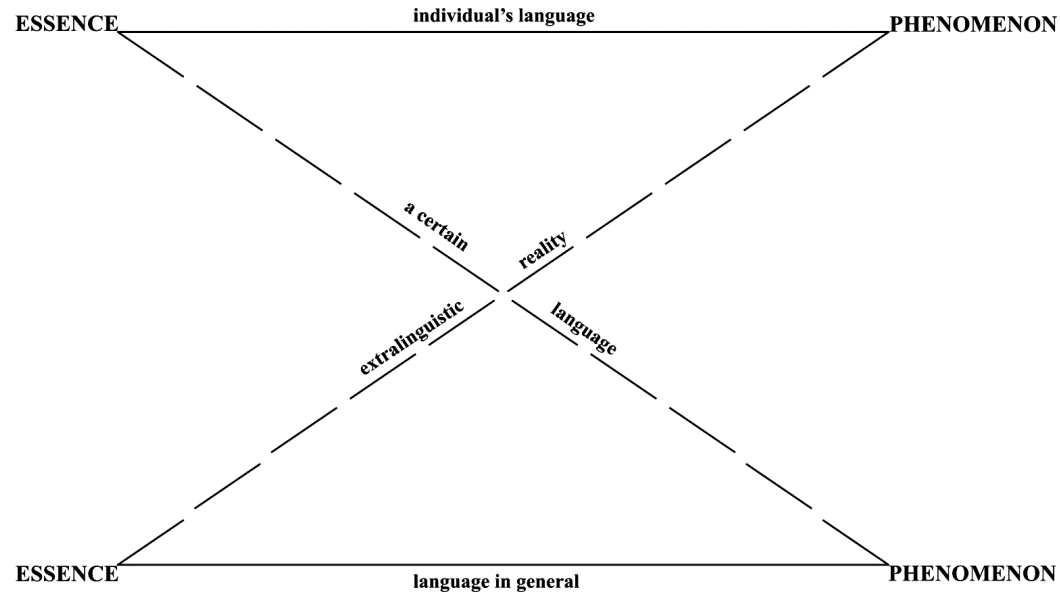

\section{Notes and References:}

1. Different linguists have considered the interrelations between language of humanity, nation's language and individual's language from various aspects. See, for example, Humboldt V. Fon O Razlichii stroeniya chelovecheskikh yazikov i ego vliyanie na dukhovnoe razvitie chelovechestva // Humboldt, V. fon (1984) Izbrannie trudi po yazikoznaniyu. M.: Progress, p.60-74; Atayan, E.R. (1981) Lezvakan ashkhari nerqin kerpavorumy ev artaqin veraberutiuny. Yerevan: Yerevani hamals. hratarakchutyun, p.23-24. Cf also Jahukyan, G.B. (1999) Universalnaya teoriya yazika. Prolegomeny $k$ substantsionalnoi lingvistike. M.: Institut yazikoznaniya. p.12-13, where the author speeks of a language of a group rather than a nation's language. 
2. It may seem that the interrelations of language in general, a certain language and individual's language, presented in the table, correspond to those of matter, form and substance as interpreted by L. Hjelmslev (see Hjelmslev, L. (1960) Propegemeny k teorii yazika // Novoye v lingvistike. M.: Izd. inostr. literaturi Vol. I, p.308-315). But in fact such a correspondence does not exist. Form as a net of abstract relations is not identical with any of three levels of generalization mentioned above and hence is not presented in the table at all. The essence and phenomenon of any level cannot be identified to matter and substance, either. It can be seen that in the table a combination of essence and phenomenon besides the two consecutive cells includes the third adjacent cell as well, whereas matter and substance would occupy only two consecutive cells.

\section{tnıpjnıGG nı tplunıjph

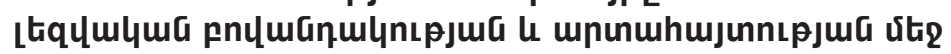

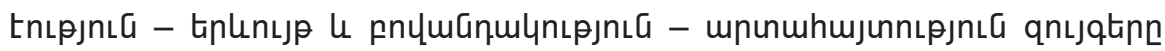

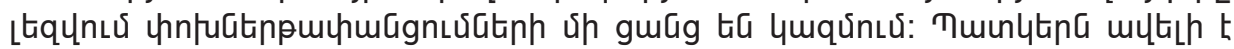

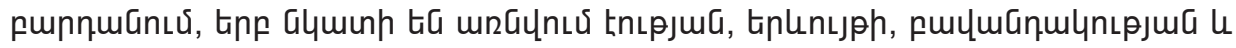

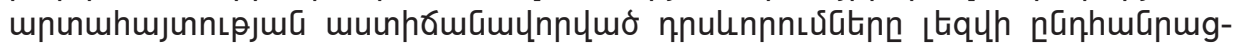

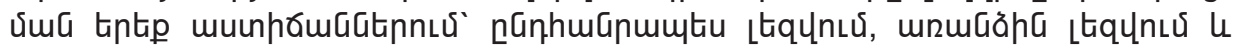

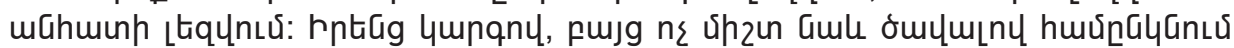

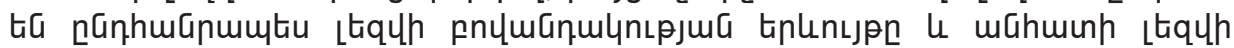

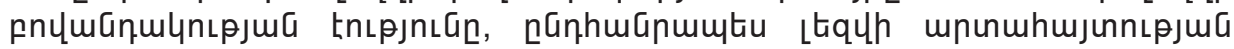

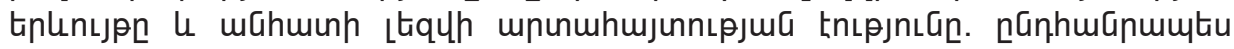

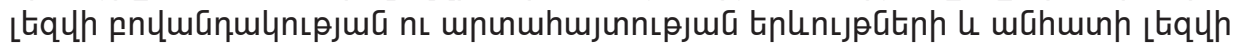

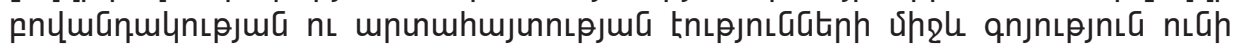

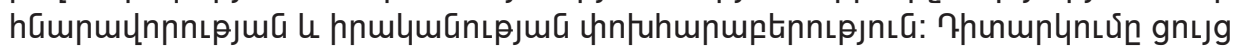

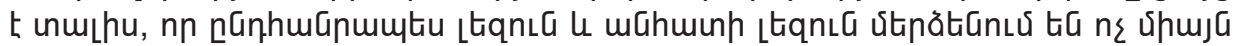

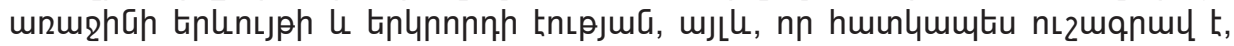

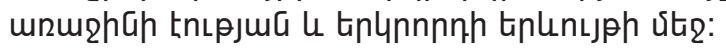

